Article

\title{
Reaction of Sweet Maize to the Use of Polyethylene Film and Polypropylene Non-Woven Fabric in the Initial Growth Phase
}

\author{
Katarzyna Adamczewska-Sowińska ${ }^{1}$ and Józef Sowiński ${ }^{2, *}$ \\ 1 Department of Horticulture, Wroclaw University of Environmental and Life Sciences, 50-375 Wrocław, \\ Poland; katarzyna.adamczewska-sowinska@upwr.edu.pl \\ 2 Institute of Agroecology and Crop Production, Wroclaw University of Environmental and Life Sciences, \\ 50-375 Wrocław, Poland \\ * Correspondence: jozef.sowinski@upwr.edu.pl; Tel.: +48-713-201-642
}

Received: 19 December 2019; Accepted: 14 January 2020; Published: 18 January 2020

\begin{abstract}
Sweet maize (Zea mays L. var. saccharata Bailey) is a valuable vegetable adapted to growing in temperate climate conditions. Temperature, especially in the beginning of the growing period, has a crucial effect on vegetation and yield. The best maize initial growth requires soil temperature above $10{ }^{\circ} \mathrm{C}$. Maize covered by polyethylene film and polypropylene non-woven fabric leads to an increase in temperatures which accelerates crop growth. Three years (2012-2014) of field experiments were carried out at the Research and Didactic Station in Psary, belonging to the Department of Horticulture of Wroclaw University of Environmental and Life Sciences. A three-factorial experiment was established using the randomized subblock method in three repetitions in the years 2012-2014. Cobs were harvested in the milk-dough phase of grain maturity. Hybrid Rustler F1 produced, on average, $35.4 \%$ more marketable yield than Signet F1. On average, 10.2\% more cobs and 22.7\% more cobs (with Hybrid Rustler F1 and Signet F1, respectively) were harvested in cases when the sowing was performed in the third decade of April. The use of covers contributed to a significant increase in the yield compared to the yield of uncovered plants. Transparent foil also contributed to a significant increase in the number of cobs harvested in the marketable yield.
\end{abstract}

Keywords: harvest acceleration; plant cover; temperature; yield

\section{Introduction}

Sweet maize (Zea mays L. var. saccharata Bailey) is grown mainly for processing and can also be sold in the form of cobs, which is a valuable addition to the daily diet. It is a source of many biologically active ingredients, e.g., $\beta$-carotene, lutein and zeaxanthin, which protect the human body against the effects of free radicals causing civilisation diseases. These compounds must be provided with food in which they are in free form or bound in the form of esters with carboxylic acids. Both forms of carotenoids are available for the human body [1]. Maize is also a source of fibre, minerals and some vitamins.

Maize is a thermophilic species adapted to growing in temperate climates [2,3]. Thermal conditions, especially in the initial growth period, have a decisive effect on the vegetation course of the plants. Stone et al. [4] report that, especially in cold climates, increasing soil temperature in the period from sowing to stem growth has a positive effect on the yield of biomass and maize grain. According to Reference [5], maize sowing is best carried out when the soil temperature is above $15-20{ }^{\circ} \mathrm{C}$. Hasell et al. [6], and Kara and Atar [7] find that maize develops faster at $25-32{ }^{\circ} \mathrm{C}$ at a later stage of growth, while a temperature above $35^{\circ} \mathrm{C}$, it has a negative effect on maize germination [8], and in the seed setting phase, it causes a decrease in yield [9]. At temperatures below $16-18{ }^{\circ} \mathrm{C}$, germination [8] 
and growth inhibition [7] are also reduced. According to Hasell et al. [6], it is important for sweet maize producers to understand the relationship between temperature, germination and initial growth vigour. The basis for successful cultivation is to plan the sowing date in such a way that there is no significant reduction in the plant density and in the initial growth rate. According to the same authors, the number of days required to reach $75 \%$ of the planned planting density is reduced from 6 days (at $11.1^{\circ} \mathrm{C}$ ) to 3 days (at $26.7^{\circ} \mathrm{C}$ ). Abd El-Hamed et al. [10] confirm that rapid emergence requires temperatures above $10^{\circ} \mathrm{C}$ and optimal conditions from emergence to flowering are $21-27^{\circ} \mathrm{C}$.

The sowing date and the length of the growing season have a significant influence on the yield of maize grain [11]. Increasing the assimilation area and accelerating photosynthesis in the initial growth period is one of the possible ways to increase maize yield [12]. In the experiments conducted by the authors of Reference [13], the grain yield was higher when the vegetation period of plants was extended.

In vegetable production, the growth of plants is deliberately accelerated in order to obtain an earlier harvest and thus higher market prices. Early sowing of maize can increase grain yield, but the plants should be protected in such a way that they cannot be exposed to low temperatures, especially in the initial phase of growth [3]. Under conditions of thermal stress caused by excessively low temperatures, weak germination of grain and slow juvenile growth limit the development of plants and, as a result, their yield and profitability of cultivation [2], particularly shrunken-2 (sh2) and sugar enhancer (se) variety types [6]. To facilitate early maize production, soil temperature should be raised to a minimum of $12.2^{\circ} \mathrm{C}$, which is necessary for root growth and nutrient uptake [14]. Rattin et al. [15] found that both the photosynthesis efficiency and the growth dynamics of the maize root system determine the yield. An agrotechnical method limiting the adverse effect of low temperature on the development of vegetables during their production is the use of covers made of polyethylene foil or polypropylene non-woven fabric either placed directly on plants and/or in the form of low foil tunnels. Flat plastic covers protect plants against frost, cold winds and heavy rainfall, and reduce evaporation of water from the soil surface $[16,17]$. Under covers made of perforated polyethylene film and polypropylene non-woven fabric, an increase in both air and soil temperatures is observed [18]. According to many studies, the use of perforated foil or polypropylene non-woven fabric contributes to the acceleration of harvest by several days, and an increase and improvement of vegetable yield quality, especially those grown for early harvest or thermophilic species [19-21]. An increase in the yield of sweet maize, courgettes and cucumbers under cover in relation to cultivation without cover was observed by References [4,19,21-23].

The aim of the study presented in this manuscript was to determine the effect of covers made of various types of polyethylene film and polypropylene non-woven fabric used in the juvenile stage of sweet maize vegetation on its development and yield. The study sought to test the hypothesis that cover crops positively influenced soil temperature and enhanced maize growth and yield. It was assumed that maize plant covering in the early vegetation period ultimately increases the marketable yield of cobs. It was also assumed that the type of sweet maize variety (very early and medium early) interacts differently with the applied experiment treatments (sowing term and cover type).

\section{Materials and Methods}

Field studies were conducted in the years 2012-2014 at the Research and Didactic Station of the Department of Horticulture at Wroclaw University of Environmental and Life Sciences $\left(51^{\circ} 19^{\prime}\right.$ $\mathrm{N}, 17^{\circ} 03^{\prime} \mathrm{E}$ ), south-west Poland. The experiment was conducted on chernozems with a calcic level (FAO-WRB Gleyic Calcic Chernozems soil) on medium clay, belonging to the medium soil class (class III) in the six-class Polish Soil Classification system. The first class represents the best soil, and the sixth soil with the lowest fertility, and humus content $1.8 \%$, pH 7.25 and salinity $103.1 \mu \mathrm{S}-\mathrm{cm}^{-1}$. A three-factorial experiment was established in three repetitions using the randomized subblock method. The growth rate and rate of yield of two sweet maize varieties were compared. Signet F1 (very early) and Rustler F1 (medium early) belonging to the super sweet group were used for the 
tests. Maize was sown $70 \times 24 \mathrm{~cm}(60,000$ per ha), on two dates (factor II). The first date depended on weather conditions and the possibility of spring soil tillage, and the second was on 25 April on an annual basis. The main characteristic data from the maize experiment are presented in Table 1. Experiment design is presented in Figure 1. Immediately after the sowing, the herbicide Lumax 537.5 SE (terbutylazine, mesotrione, S-metolachlor) was sprayed in the amount of $3.5 \mathrm{~L} \mathrm{ha}^{-1}$. Then, the plots were covered with colourless (PE), red (PER) or green (PEG) polyethylene foil, as well as polypropylene non-woven fabric (PP) (factor III). Strips of foil and non-woven fabric, $200 \mathrm{~cm}$ wide, were placed on metal arches and attached to the ground with plastic pins. The height of the structure was $40 \mathrm{~cm}$. The coverings remained on the plants for 4-6 weeks (depending on the weather and maize growth dynamics). The control units were plots without covers. In total, the experiment included 20 combinations. The size of each plot was $10.5 \mathrm{~m}^{2}(7.5 \times 1.4 \mathrm{~m})$.

Table 1. Maize experiment characteristic.

\begin{tabular}{ccccccc}
\hline Year & \multicolumn{2}{c}{$\mathbf{2 0 1 2}$} & \multicolumn{2}{c}{$\mathbf{2 0 1 3}$} & \multicolumn{2}{c}{$\mathbf{2 0 1 4}$} \\
\hline Sowing Term & 18 April & 25 April & 15 April & 25 April & 08 April & 25 April \\
\hline Cover take off & \multicolumn{2}{c}{ 21 May } & \multicolumn{2}{c}{ 29 May } & 19 May \\
\hline $\begin{array}{c}\text { Number of days from sowing to } \\
\text { cover take off }\end{array}$ & 34 & 27 & 45 & 35 & 38 & 24 \\
\hline $\begin{array}{c}\text { Average air temperature between } \\
\text { sowing and cover take off }\left({ }^{\circ} \mathrm{C}\right)\end{array}$ & 15.0 & 16.0 & 14.0 & 14.1 & 12.0 & 12.3 \\
\hline Harvest period & 17 July-06 August & 25 July-14 August & 22 July-09 August \\
\hline
\end{tabular}
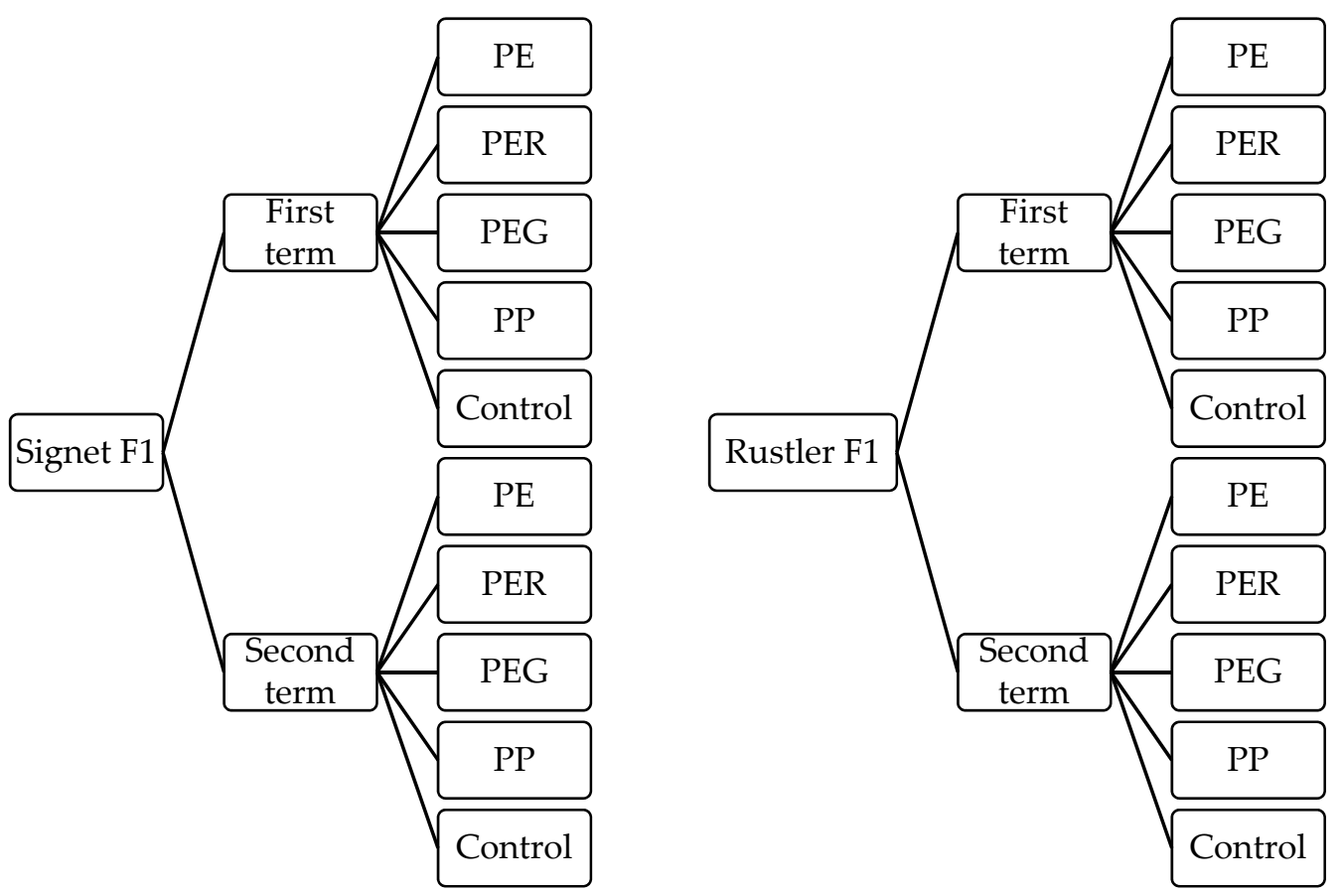

Figure 1. Field experiment layout. PE-polyethylene foil (colourless); PER—red polyethylene foil; PEG—green polyethylene foil; PP—non-woven fabric; Control—without cover.

The preparation of the field for the experiment was performed by deep pre-winter ploughing, and in spring by tillage and harrowing. Maize was cultivated at a soil content of $60 \mathrm{mg} \mathrm{P} \mathrm{dm}^{-3}$ and $200 \mathrm{mg} \mathrm{K} \mathrm{dm}^{-3}$. $\mathrm{N}$ fertilization in the form of ammonium nitrate was performed before maize sowing, in the amount of $70 \mathrm{~kg} \mathrm{~N} \mathrm{ha}^{-1}$, and after removing covers at $50 \mathrm{~kg} \mathrm{~N} \mathrm{ha}^{-1}$.

On removing the foil and the non-woven fabric, the height of the plants and the number of leaves as well as the leaf greenness index (SPAD) were evaluated using N-Tester. After one month, the height 
of plants was evaluated. At harvest time, the length, diameter and weight of flasks were determined. Harvesting was performed in each site once, in the milk-dough phase of grain maturity (in $\mathrm{BBCH}$ scale 73-75). The marketable yield of cobs and the number of cobs per area unit were determined. The marketable yield consisted of well-grown cobs filled with grain of optimal maturity.

During the harvest, chemical analyses of maize grain were performed, where grain was assessed for its content of: dry mass-using the weighing method (content determination PN-90/A-75101/03), vitamin C - using the titration method (content determination PN-90/A-75101/11), reducing sugars-using the Lane-Eynon method (content determination PN-90/A-75101/07), and carotenoids-using the colorimetric method. The dry mass of the maize grain was used to calorimetrically analyses and mark the content of $\mathrm{P}$ and $\mathrm{Mg}$ in $2 \%$ acetic acid, whilst the content of $\mathrm{K}$ and Ca was measured by means of the flame photometry method.

At the site of the experiment, air temperature was recorded continuously using an electronic recorder (TempLogger AZ 8828) and precipitation measurements were taken with a Hellmann rain gauge. The obtained data were compared with data for the years 1971-2010 from the Institute of Meteorology and Water Management. The temperature of soil at the depth of $5 \mathrm{~cm}$ was also recorded until the covers were removed.

The number of days from sowing to harvesting maturity and the number of thermal units ( $\mathrm{T}$ baseline $=10^{\circ} \mathrm{C}$ ) from sowing to harvesting (based on soil temperature) and to harvesting maturity (based on ambient air temperature) were calculated as growing degree days (GDD). The calculation of thermal units provided estimates for the prediction of a plant's growth and development within the growing season. The main assumption of GDD was based on a base temperature (T-base) specific for different crops and crop (e.g., maize) development, which occurs when the temperature is over a given minimum. Crop coverings, such as plastic films and polypropylene non-woven fabric, lead to an increase in observed temperatures and a similar influence on the accumulation of GDD.

The results of the sweet maize study (plant biometric parameters, cobs parameters, cobs yield and maize grain quality) were statistically elaborated with the variance analysis method processed by three-way analysis of variance (ANOVA). Mean values were compared using the Tukey test for the level of significance $\alpha=0.05$. The methods of sweet maize management treatment were entered as a fixed effect in the analysis and replications were considered random effects. The calculations were performed using the Statistica (version 13.1 StatSoft, Poland) software package [24]. Excel and PowerPoint software were used to draw graphs.

\section{Results}

\subsection{Environmental Conditions}

Throughout the research period, a higher air temperature than the long-term average air temperature was recorded during the maize vegetation period (Table 2). Much higher than average temperatures were observed during plant emergence (i.e., within weeks of maize sowing) in 2012 and 2014. In the subsequent years of the study during the maize vegetation period, large precipitation water deficits were observed, ranging from 95.6 to $104.6 \mathrm{~mm}$, in relation to the average long-term precipitation totals (Table 2). However, the most unfavourable distribution of precipitation between April and August occurred in 2013. The period of seed germination and plant emergence was very unfavourable in this respect. The long rain-free period, in March and April, and the accumulated high rainfall in the short period from 30 April to 9 May $(79.6 \mathrm{~mm})$, caused a delay in plant emergence. This was followed by flooding of the experiment site. In the second and third part of May, no precipitation was recorded. 
Table 2. Mean air temperature and sum of rainfall during the growing period of tomato in 2012-2014.

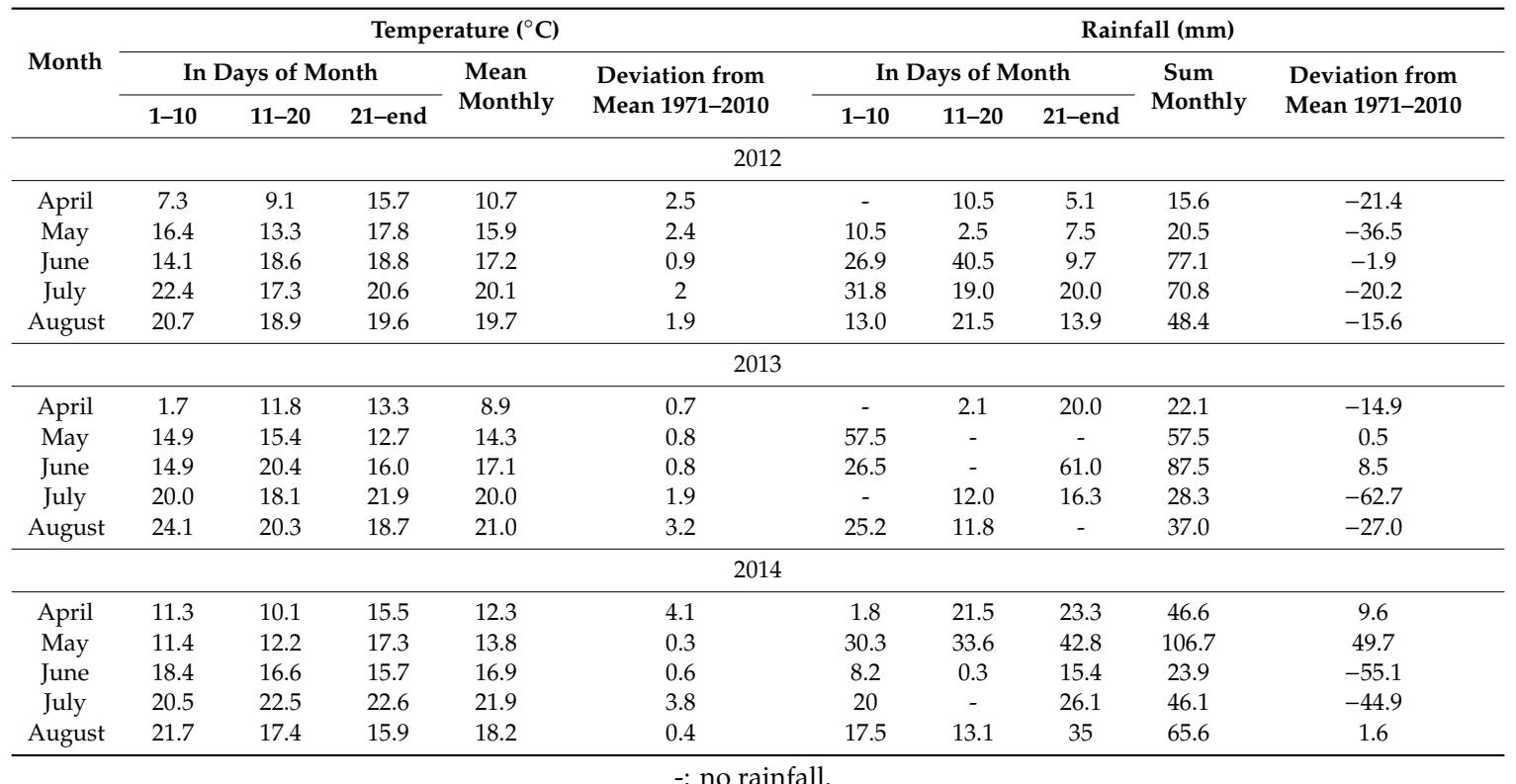

In 2012, high temperatures were observed throughout the whole period of plant covering, and for the first and second sowing dates, these were on average $15.0^{\circ} \mathrm{C}$ and $16.0^{\circ} \mathrm{C}$, respectively (Table 1$)$. In 2013 and 2014 , temperature was recorded at the level of $14.0^{\circ} \mathrm{C}$ and $14.1^{\circ} \mathrm{C}$, and $12.0^{\circ} \mathrm{C}$ and $12.3^{\circ} \mathrm{C}$ respectively, for the two sowing dates.

Worse thermal conditions in 2014 were confirmed by lower total effective temperatures. These amounted to 660.9 during the growth period of plants sown on the first date and 710 for the second date of sowing (Figure 2). In 2012, the total effective temperatures were $13.4 \%$ and $10.1 \%$ higher respectively, and in 2013, 21.4\% and $9.2 \%$ higher.

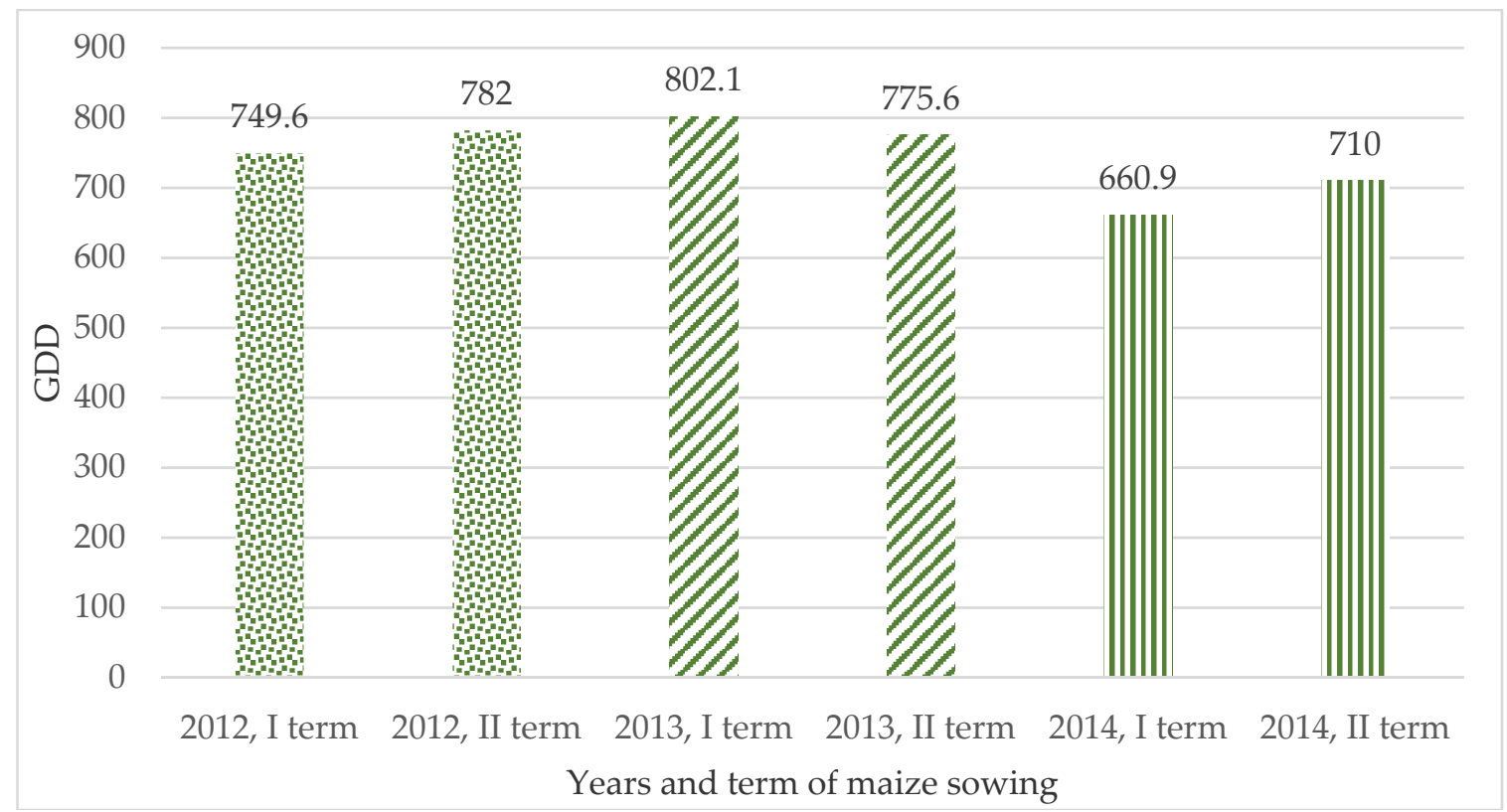

Figure 2. Growing degree days during the sweet maize vegetation period.

Measurements of soil temperature were taken in the zone where maize seeds were placed, and their germination showed a large variation depending on the year of testing and the covers used. It was 
found that, within a week of the first date of sowing, the average temperature of uncovered soil was, depending on the year, from 10.3 to $15.6^{\circ} \mathrm{C}$, and in the second period, from 14.8 to $20.3{ }^{\circ} \mathrm{C}$ (Table 3 ).

Table 3. Average soil temperature at $5 \mathrm{~cm}$ soil depth in the years $2012-2014\left({ }^{\circ} \mathrm{C}\right)$.

\begin{tabular}{|c|c|c|c|c|c|c|c|c|c|c|c|c|}
\hline \multirow{3}{*}{$\begin{array}{l}\text { Cover } \\
\text { Type }\end{array}$} & \multicolumn{4}{|c|}{$\begin{array}{c}\text { Mean Temperature throughout the } \\
\text { Covering Period }\end{array}$} & \multicolumn{8}{|c|}{ Mean Temperature within the First Week after Sowing } \\
\hline & \multirow{2}{*}{2012} & \multirow{2}{*}{2013} & \multirow{2}{*}{2014} & \multirow{2}{*}{ Mean } & \multicolumn{4}{|c|}{ I Term } & \multicolumn{4}{|c|}{ II Term } \\
\hline & & & & & 2012 & 2013 & 2014 & Mean & 2012 & 2013 & 2014 & Mean \\
\hline $\mathrm{PE}$ & 21.8 & 20.1 & 17.9 & 19.9 & 15.9 & 18.1 & 13.5 & 15.8 & 24.5 & 17.7 & 18.8 & 20.3 \\
\hline PER & 21.8 & 18.6 & 17.8 & 19.4 & 16.9 & 16.9 & 13.6 & 15.8 & 24.0 & 16.0 & 18.5 & 19.5 \\
\hline PEG & 20.6 & 18.6 & 17.4 & 18.8 & 16.1 & 16.3 & 12.4 & 14.9 & 22.7 & 15.7 & 18.5 & 19.0 \\
\hline $\mathrm{PP}$ & 20.6 & 17.6 & 15.2 & 17.8 & 15.2 & 16.4 & 11.5 & 14.4 & 22.6 & 15.5 & 16.2 & 18.1 \\
\hline Control & 18.8 & 17.8 & 14.7 & 17.1 & 14.1 & 15.6 & 10.3 & 13.3 & 20.3 & 14.8 & 15.8 & 17.0 \\
\hline Mean & 20.7 & 18.6 & 16.6 & - & 15.6 & 16.7 & 12.3 & - & 22.8 & 15.9 & 17.6 & - \\
\hline
\end{tabular}

The highest sum of effective temperatures after one week from the first sowing date was found in 2013 (Figure 3A). In 2012 and 2014, this sum was 11.4\% lower and almost three times lower, respectively (Figure 3C,E). On the seventh day after the second sowing date, the highest sum of temperatures was recorded in 2012. In 2013, this was 19\% lower, and in 2014, about half as low. On the second sowing date, the highest increase in the sum of effective temperatures was observed in 2014. In 2012 , the initial vegetation period on the second date of sowing occurred in the cold period and the increase in the total effective temperatures was the lowest (Figure 3B-F).

During the period from sowing the seeds to removal of covers, the average temperature of uncovered soil was, depending on the year, from 14.7 to $18.8^{\circ} \mathrm{C}$. The use of covers immediately after sowing the seeds led to a significant increase in temperature, on average by $0.7^{\circ} \mathrm{C}$ (PP non-woven fabric) to $2.8^{\circ} \mathrm{C}$ (transparent PE film). The beneficial influence of shields can also be seen on the light of the total effective temperatures. Its highest increase in relation to control plots at an earlier sowing date was observed under colourless and red foil (49.6\% and $43.3 \%$, respectively), and at a later date, under colourless foil, $45.6 \%$. The use of PEG film and PP non-woven fabric resulted in an increase in GDD of $35.9 \%$ and $31.5 \%$ as well as of $16.6 \%$ and $13.5 \%$. In all the years of the study, the shields demonstrated a beneficial effect on soil temperature, but this effect was not uniform. As shown by the results of measurements (Figure 1C,E), the most uniform heating of soil, at both the first and second date of sowing, was observed in 2013. The smallest differences between the soil temperature in the plots without protection and in the protected ones were also visible here. They were $16.8 \%$ on average for the first sowing date and $15.3 \%$ for the second one. In 2012, these differences amounted to $39.4 \%$ and $37.9 \%$ respectively, and in $2014,73.2 \%$ and $58.8 \%$. 


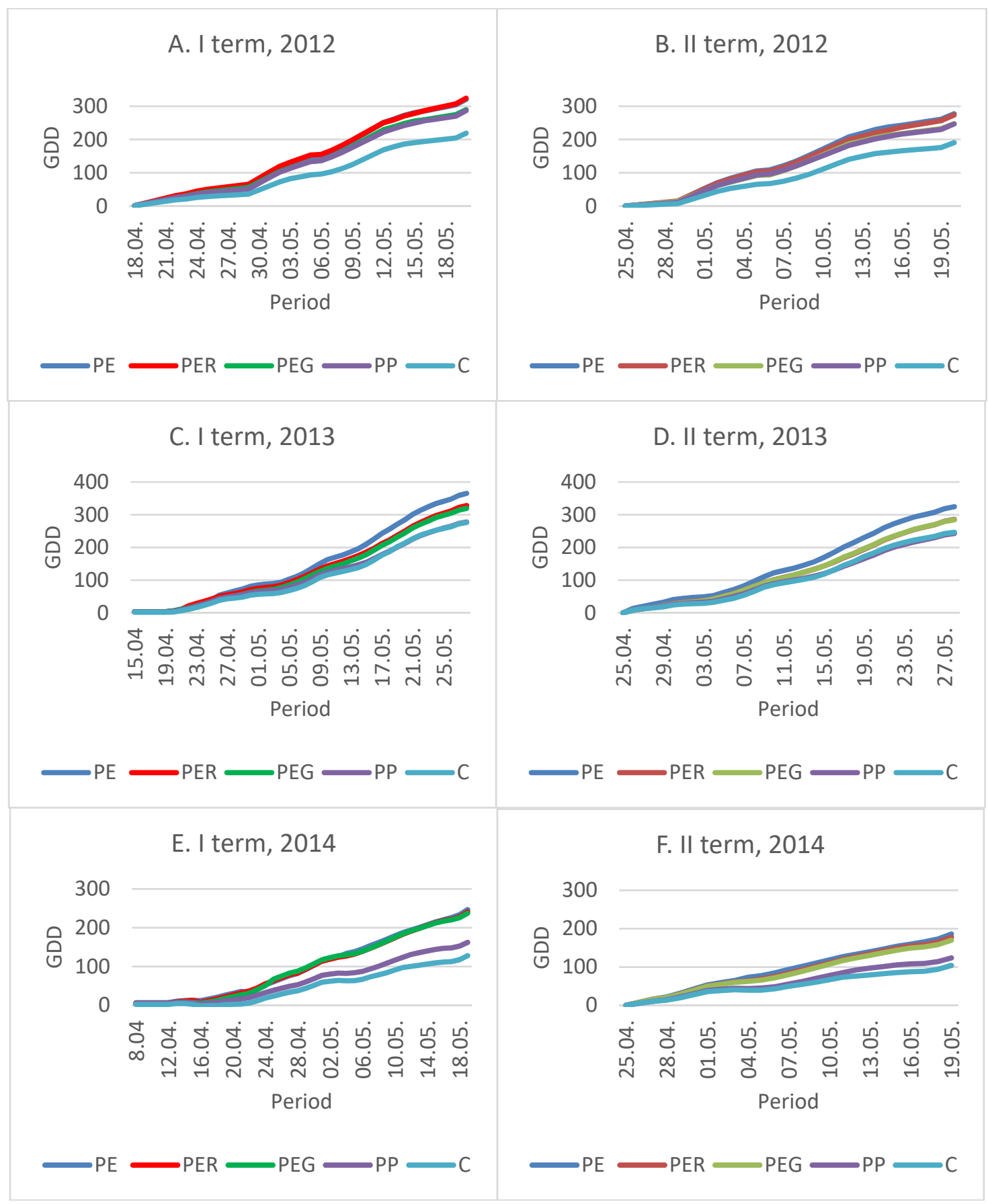

Figure 3. Cumulative sum of mean daily temperature within maize plant cover period $\left({ }^{\circ} \mathrm{C}\right)$. (A) First sowing term 2012, (B) second sowing term 2012, (C) first sowing term 2013, (D) second sowing term 2013, (E) first sowing term 2014, (F) second sowing term 2014.

\subsection{Biometric Measurements after Removal of the Shields}

It was also found that the investigated varieties, both immediately after the removal of the covers and subsequently, reached a similar height (Table 4). In the Rustler F1 variety, however, a $10 \%$ higher leaf greenness index SPAD was found. 
Table 4. The effect of treatments on maize plants. Mean from the years 2012-2014.

\begin{tabular}{|c|c|c|c|c|c|c|c|c|c|c|}
\hline \multirow{2}{*}{$\begin{array}{l}\text { Sowing } \\
\text { Term (St) }\end{array}$} & \multirow{2}{*}{$\begin{array}{c}\text { Cover } \\
\text { Type (Ct) }\end{array}$} & \multicolumn{6}{|c|}{ Directly after Cover Take off } & \multicolumn{3}{|c|}{$\begin{array}{l}\text { Plant Height One Month after } \\
\text { Cover Take off }(\mathrm{cm})\end{array}$} \\
\hline & & \multicolumn{3}{|c|}{ Plant Height (cm) } & \multicolumn{3}{|c|}{ SPAD } & Signet $F_{1}$ & Rustler $\mathrm{F}_{1}$ & Mean \\
\hline \multirow{4}{*}{ I } & $\mathrm{PE}$ & 31.3 & 33.3 & 32.3 & 468 & 507 & 487 & 163.2 & 157.2 & 160.2 \\
\hline & PER & 32.8 & 31.2 & 32.0 & 404 & 476 & 440 & 150.4 & 149.3 & 149.8 \\
\hline & PEG & 30.0 & 31.9 & 31.02 & 397 & 415 & 406 & 149.3 & 141.5 & 145.4 \\
\hline & mean & 28.5 & 30.5 & 29.5 & 433 & 473 & 453 & 150.0 & 144.4 & 147.2 \\
\hline \multirow{4}{*}{ II } & $\mathrm{PE}$ & 24.9 & 23.5 & 24.2 & 476 & 494 & 485 & 146.4 & 135.8 & 141.1 \\
\hline & PER & 33.4 & 25.7 & 29.6 & 471 & 543 & 507 & 151.2 & 162.1 & 156.6 \\
\hline & PEG & 28.5 & 26.9 & 27.7 & 475 & 566 & 521 & 144.6 & 149.3 & 146.9 \\
\hline & $\mathrm{PP}$ & 25.5 & 24.1 & 24.8 & 466 & 530 & 498 & 141.7 & 132.3 & 137.0 \\
\hline \multirow{4}{*}{ mean } & PER & 33.1 & 28.5 & 30.8 & 438 & 510 & 474 & 150.8 & 155.7 & 153.2 \\
\hline & PEG & 29.3 & 29.4 & 29.3 & 436 & 491 & 463 & 146.9 & 145.4 & 146.2 \\
\hline & PP & 26.1 & 28.2 & 27.1 & 453 & 506 & 479 & 144.7 & 142.0 & 143.4 \\
\hline & control & 20.0 & 20.3 & 20.1 & 466 & 484 & 475 & 135.8 & 121.1 & 128.5 \\
\hline \multicolumn{2}{|c|}{$\begin{array}{l}\text { Mean from cultivars } \\
\qquad(\mathrm{Cv})\end{array}$} & 27.3 & 27.0 & & 453 & 498 & & 146.6 & 142.1 & \\
\hline \multicolumn{2}{|c|}{$\mathrm{LSD}_{\alpha=0,05}$ for: $\mathrm{CV}$} & & & n.s. & & & 33.4 & & & n.s. \\
\hline \multicolumn{2}{|c|}{ St } & & & 3.6 & & & 15.4 & & & 3.3 \\
\hline \multicolumn{2}{|r|}{$\mathrm{Ct}$} & & & 2.3 & & & n.s. & & & 5.9 \\
\hline \multicolumn{2}{|r|}{$\mathrm{Cv} \times \mathrm{Ct}$} & & & n.s. & & & 38.9 & & & 9.5 \\
\hline \multicolumn{2}{|r|}{ St $\times \mathrm{Ct}$} & & & n.s. & & & 25.3 & & & 8.1 \\
\hline \multicolumn{2}{|r|}{$\mathrm{Cv} \times \mathrm{St} \times \mathrm{Ct}$} & & & n.s. & & & 31.8 & & & n.s. \\
\hline
\end{tabular}

The morphological features of plants of both varieties were determined by the date of sowing. The observations made on the day of cover removal showed that the plants sown on the first date were $19.4 \%$ higher, but at the same time, these were less coloured (SPAD value $9 \%$ lower) in comparison with those from the second date of sowing. Measurements made after one month revealed a continued difference (on average $4 \%$ ) in plant height. The date of maize sowing did not affect the size of cobs in a differentiating way.

Based on the research results, it was found that the installation of covers made of foil or non-woven fabric on maize fields was conducive to plant development. Immediately after removal of the covers, their height was on average $43.7 \%$ higher than that of maize in the control plots. The measurement of leaf greenness did not show any significant differences in colour between the sites, but it was noted that the highest SPAD index was found for the leaves of plants covered with transparent PE foil. Measurements made after one month confirmed the difference in plant height. Maize covered with transparent or red perforated foil was on average 18.2\% higher than that in the control plot. After the application of PP or green PE film, the difference was $12.7 \%$ on average. At that time of observation, a significant interaction between the sowing date and the type of cover was observed. Plants covered after sowing on the first date were on average 13.4\% higher (and 22.5\% higher under transparent foil), while those sown on the second date were $12.3 \%$ higher (24.1\% higher under red PE foil) in comparison with the control plot.

Significant differences between the varieties were noted during the harvest (Table 5). It was found that the Rustler F1 variety, compared to Signet F1, had slightly longer cobs with a larger diameter and their weight was on average $9 \%$ greater. During the experiment period, the Rustler F1 variety produced, on average, more even cobs, whose mass was 271.9 and $272.6 \mathrm{~g}$ (a difference of $0.7 \mathrm{~g}$ ) for first and second sowing term, respectively. For Signet F1, delay in sowing had a positive effect on the weight of the cobs, which increased from 247.4 to $252.4 \mathrm{~g}$ ( $5 \mathrm{~g}$ difference). 
Observations made during the harvest showed that plants covered with transparent PE foil were characterised by a better quality of cobs (Table 5). It was found that the unit weight of cobs from these plants was on average $9.3 \%$ and $12.8 \%$ higher than in plants covered with non-woven fabric and those in control plots, and the diameter of their cobs was on average $7.2 \%$ higher. At the same time, it was also found that the cobs of maize grown without covers were the longest. The same homogeneous group included the cob length of plants covered with polypropylene non-woven fabric.

Table 5. The effect of treatments on maize cobs. Mean from the years 2012-2014.

\begin{tabular}{|c|c|c|c|c|c|c|c|c|c|c|}
\hline \multirow{2}{*}{$\begin{array}{c}\text { Sowing } \\
\text { Term (St) }\end{array}$} & \multirow{2}{*}{$\begin{array}{c}\text { Cover } \\
\text { Type }(C t)\end{array}$} & \multicolumn{3}{|c|}{ Cob Length (cm) } & \multicolumn{3}{|c|}{ Cob Weight (g) } & \multicolumn{3}{|c|}{ Cob Diameter (cm) } \\
\hline & & Signet $F_{1}$ & Rustler $\mathbf{F}_{1}$ & Mean & Signet $F_{1}$ & Rustler $\mathbf{F}_{1}$ & Mean & Signet $F_{1}$ & Rustler $\mathbf{F}_{1}$ & Mean \\
\hline \multirow{4}{*}{ I } & $\mathrm{PE}$ & 20.0 & 20.8 & 20.4 & 264.6 & 290.6 & 277.6 & 4.8 & 4.8 & 4.8 \\
\hline & PEG & 19.4 & 20.6 & 20.0 & 254.8 & 279.1 & 267.0 & 4.6 & 4.8 & 4.7 \\
\hline & $\mathrm{PP}$ & 20.3 & 20.3 & 20.3 & 244.3 & 251.4 & 247.8 & 4.5 & 4.7 & 4.6 \\
\hline & control & 20.2 & 20.9 & 20.5 & 211.3 & 261.7 & 236.5 & 4.2 & 4.6 & 4.4 \\
\hline \multirow{6}{*}{ II } & $\mathrm{PE}$ & 19.8 & 20.0 & 19.9 & 270.4 & 265.6 & 268.0 & 4.6 & 4.7 & 4.7 \\
\hline & PER & 19.7 & 20.4 & 20.0 & 269.7 & 285.0 & 277.4 & 4.8 & 4.7 & 4.8 \\
\hline & PEG & 19.9 & 20.1 & 20.0 & 257.9 & 285.8 & 271.9 & 4.6 & 4.7 & 4.6 \\
\hline & $\mathrm{PP}$ & 19.9 & 20.8 & 20.3 & 225.9 & 273.4 & 249.7 & 4.5 & 4.6 & 4.5 \\
\hline & control & 20.0 & 20.9 & 20.4 & 238.1 & 253.3 & 245.7 & 4.5 & 4.3 & 4.4 \\
\hline & mean & 19.9 & 20.4 & 20.1 & 252.4 & 272.6 & 262.5 & 4.6 & 4.6 & 4.6 \\
\hline \multirow{2}{*}{ mean } & $\mathrm{PP}$ & 20.1 & 20.5 & 20.3 & 235.1 & 262.4 & 248.8 & 4.5 & 4.6 & 4.5 \\
\hline & control & 20.1 & 20.9 & 20.5 & 224.7 & 257.5 & 241.1 & 4.4 & 4.5 & 4.4 \\
\hline \multicolumn{2}{|c|}{ Mean from cultivar $(\mathrm{Cv})$} & 19.9 & 20.5 & & 249.9 & 272.3 & & 4.6 & 4.7 & \\
\hline \multirow{3}{*}{\multicolumn{2}{|c|}{$\begin{array}{c}\mathrm{LSD}_{\alpha=0.05} \text { for: } \mathrm{Cv} \\
\mathrm{St} \\
\mathrm{Ct}\end{array}$}} & & & 0.19 & & & 10.68 & & & 0.08 \\
\hline & & & & n.s. & & & n.s. & & & n.s. \\
\hline & & & & 0.24 & & & 11.82 & & & 0.10 \\
\hline \multicolumn{2}{|r|}{$\mathrm{Cv} \times \mathrm{St}$} & & & n.s. & & & n.s. & & & 0.10 \\
\hline \multicolumn{2}{|r|}{$\mathrm{Cv} \times \mathrm{St} \times \mathrm{Ct}$} & & & 0.48 & & & 23.6 & & & 0.20 \\
\hline
\end{tabular}

\subsection{Yield Results}

The studies indicate a significant influence of the conditions prevailing in the years of research, maize variety and date of sowing, as well as the type of cover on the yield and number of harvested cobs (Table 6). Despite comparatively favourable thermal conditions during the emergence and vegetation of maize in the subsequent years, it was found that the number of emerging plants and their later plant density, and as a result the yield of cobs, were very differentiated. Insufficient precipitation at the crucial moments of maize development or their uneven distribution were a limiting factor. The year 2013, in particular, turned out to be unfavourable in this respect, as the number of cobs in the commercial crop was $47.2 \%$ and 37.3\% lower than in 2012 and 2014, and the average yield was twice as low.

Rustler F1 produced, on average, 35.4\% more cobs in the marketable yield and 51\% more cobs than Signet F1. On average, $10.2 \%$ and $22.7 \%$ more cobs were harvested in the event that sowing was performed in the third decade of April. The difference in marketable yield between the varieties was visible with both sowing dates, but at earlier sowing it was much higher, amounting to $82.4 \%$, and $50 \%$ more cobs were then collected from the Rustler F1 variety.

The use of covers at the beginning of maize vegetation contributed to a significant increase in the yield compared to the yield of uncovered plants. This increase ranged from an average of $16.5 \%$ (PER, PP, PEG) to $33.4 \%$ (PE). Transparent foil sheeting also contributed to a significant increase in the number of cobs harvested in the marketable yield per unit area-32.9\% compared to the control plot and on average, $18.6 \%$ compared to the plots covered by PP, PER and PEG. 
The present study did not show any significance for the interaction between the sowing date and the type of cover, but certain tendencies were found. A more noticeable effect of coverings on maize yielding was observed at a later sowing date. The increase in yield in relation to uncovered plants was, on average, 36.4\% (transparent PE, red PE) and 22.6\% (green PP, green PE). A significant increase in the yield of cobs (by 25.7\%) in the case of sowing seed at the first date was recorded after covering the plants with transparent PE. In the remaining plots, the yield was at a similar level to that in cultivation without covering the plants. The studied varieties reacted differently to the type of cover. The highest yield of cobs was obtained in the cultivation of the Rustler F1 variety using transparent and red PE. On average, $8 \%$ lower yield was obtained from plots covered with green PE and $22.5 \%$ lower in control plots. The highest yield of the Signet F1 variety remained at the same level of significance as the yield of uncovered plants of Rustler F1.

Table 6. The effect of treatments on maize cob yield. Mean from the years 2012-2014.

\begin{tabular}{|c|c|c|c|c|c|c|c|}
\hline \multirow{2}{*}{$\begin{array}{l}\text { Sowing } \\
\text { Term (St) }\end{array}$} & \multirow{2}{*}{$\begin{array}{c}\text { Cover } \\
\text { Type }(C t)\end{array}$} & \multicolumn{3}{|c|}{ Cob Yield (t ha-1) } & \multicolumn{3}{|c|}{ Number of Market Cobs $\left(\times 1000 \mathrm{ha}^{-1}\right)$} \\
\hline & & Signet $F_{1}$ & Rustler $F_{1}$ & Mean & Signet $F_{1}$ & Rustler $F_{1}$ & Mean \\
\hline \multirow{6}{*}{ I } & PE & 102.06 & 178.04 & 140.05 & 39.89 & 51.53 & 45.71 \\
\hline & PER & 73.07 & 161.59 & 117.33 & 29.31 & 44.87 & 37.09 \\
\hline & PEG & 71.53 & 152.91 & 112.22 & 27.30 & 50.79 & 39.05 \\
\hline & $\mathrm{PP}$ & 102.44 & 148.99 & 125.72 & 34.71 & 46.46 & 40.58 \\
\hline & control & 80.53 & 142.22 & 111.38 & 26.88 & 43.94 & 35.40 \\
\hline & mean & 85.93 & 156.75 & 121.34 & 31.62 & 47.51 & 39.57 \\
\hline \multirow{6}{*}{ II } & PE & 171.06 & 167.47 & 169.26 & 49.63 & 53.12 & 51.38 \\
\hline & PER & 122.28 & 196.62 & 159.45 & 36.61 & 47.62 & 42.11 \\
\hline & PEG & 125.08 & 170.58 & 147.83 & 37.46 & 49.74 & 43.60 \\
\hline & $\mathrm{PP}$ & 118.25 & 176.99 & 147.62 & 37.88 & 48.57 & 43.23 \\
\hline & control & 110.53 & 130.46 & 120.49 & 33.65 & 41.69 & 37.67 \\
\hline & mean & 129.44 & 168.43 & 148.93 & 39.05 & 48.15 & 43.60 \\
\hline \multirow{5}{*}{ mean } & PE & 136.56 & 172.76 & 154.66 & 44.76 & 52.33 & 48.54 \\
\hline & PER & 97.67 & 179.11 & 138.39 & 32.96 & 46.24 & 39.60 \\
\hline & PEG & 98.31 & 161.74 & 130.03 & 32.38 & 50.26 & 41.32 \\
\hline & PP & 110.35 & 162.99 & 136.67 & 36.30 & 47.51 & 41.90 \\
\hline & control & 95.53 & 136.34 & 115.93 & 30.26 & 42.80 & 36.53 \\
\hline \multicolumn{2}{|c|}{ Mean from cultivar $(\mathrm{Cv})$} & 107.68 & 162.59 & - & 35.33 & 47.83 & - \\
\hline \multicolumn{2}{|c|}{$\mathrm{LSD}_{\alpha=0.05}$ for: $\mathrm{Cv}$} & & & 8.44 & & & 2.84 \\
\hline \multicolumn{2}{|c|}{ St } & & & 10.66 & & & 2.91 \\
\hline \multicolumn{2}{|c|}{$\mathrm{Ct}$} & & & 11.71 & & & 2.91 \\
\hline \multicolumn{2}{|c|}{$\mathrm{Cv} \times \mathrm{St}$} & & & 13.60 & & & 4.07 \\
\hline \multicolumn{2}{|c|}{$\mathrm{Cv} \times \mathrm{Ct}$} & & & 17.03 & & & 4.64 \\
\hline \multicolumn{2}{|c|}{ St $\times C t$} & & & n.s. & & & n.s. \\
\hline \multicolumn{2}{|c|}{$\mathrm{Cv} \times \mathrm{St} \times \mathrm{Ct}$} & & & 23.42 & & & n.s. \\
\hline
\end{tabular}

n.s.-no significant.

\subsection{Chemical Composition}

Based on the results of chemical analyses, it was shown that sweet maize grains contained on

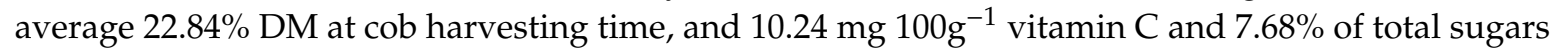
in fresh weight (Table 7). In $100 \mathrm{~g}$ DM, on average, $1.06 \mathrm{mg}$ carotenoids were determined. It was found that the Signet F1 variety had a lower average dry matter content compared to Rustler F1. At the same time, $17.6 \%$ higher phosphorus, $20.8 \%$ higher potassium and $16.7 \%$ higher calcium were determined in grain of Rustler F1 variety (Table 8). On the other hand, the total sugar content was 1 pp higher than in Rustler F1, but this difference was not statistically proven. 
Table 7. Dry matter content, vitamin C, carotenoids and sugar total in sweet maize grain depending on varieties and type of cover. Mean from the years 2012-2014.

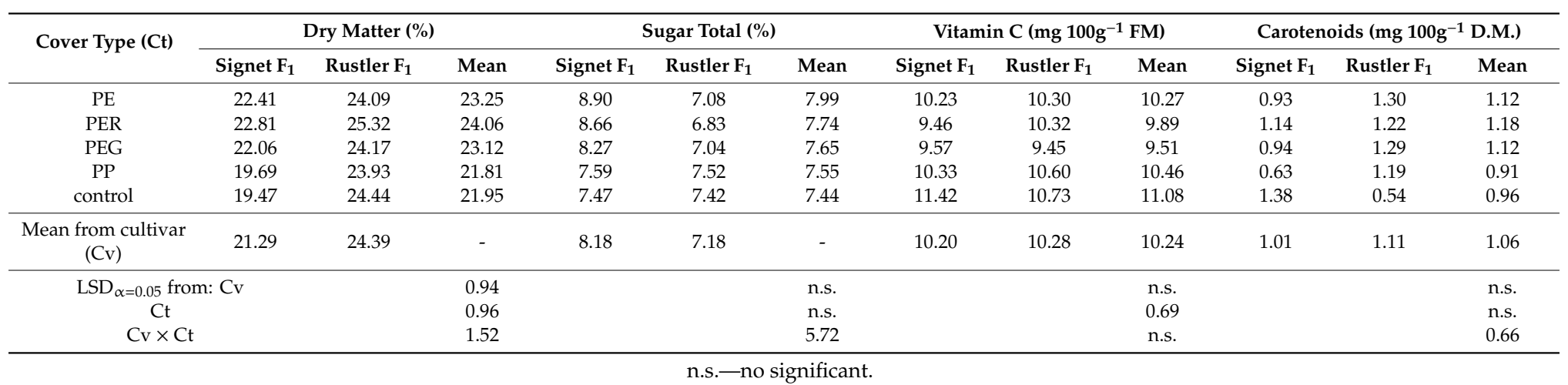

Table 8. Macro nutrients content in sweet maize grain depending on varieties and type of cover. Mean from the years 2012-2014.

\begin{tabular}{|c|c|c|c|c|c|c|c|c|c|c|c|c|}
\hline \multirow{3}{*}{ Cover Type (Ct) } & \multicolumn{3}{|c|}{$\mathbf{P}$} & \multicolumn{3}{|c|}{$\mathrm{K}$} & \multicolumn{3}{|c|}{$\mathrm{Mg}$} & \multicolumn{3}{|c|}{$\mathrm{Ca}$} \\
\hline & \multicolumn{12}{|c|}{ mg 100g-1 D.M. } \\
\hline & Signet $F_{1}$ & Rustler $F_{1}$ & Mean & Signet $F_{1}$ & Rustler $\mathrm{F}_{1}$ & Mean & Signet $F_{1}$ & Rustler $\mathrm{F}_{1}$ & Mean & Signet $F_{1}$ & Rustler $\mathrm{F}_{1}$ & Mean \\
\hline PE & 272.60 & 240.50 & 256.55 & 1222.3 & 1144.3 & 1183.3 & 131.00 & 144.50 & 137.75 & 187.10 & 160.85 & 173.98 \\
\hline PER & 280.50 & 225.90 & 253.20 & 1321.0 & 1129.9 & 1225.5 & 151.50 & 154.25 & 152.88 & 195.10 & 173.00 & 184.05 \\
\hline PEG & 281.70 & 238.20 & 259.95 & 1382.8 & 1173.3 & 1278.1 & 133.50 & 151.30 & 142.40 & 179.10 & 167.85 & 173.48 \\
\hline PP & 286.20 & 239.70 & 262.95 & 1516.6 & 1195.8 & 1356.2 & 140.00 & 138.75 & 139.38 & 184.90 & 152.35 & 168.63 \\
\hline control & 298.80 & 262.90 & 280.85 & 1571.9 & 1166.3 & 1369.1 & 154.70 & 137.50 & 146.10 & 188.50 & 147.10 & 167.80 \\
\hline $\begin{array}{l}\text { Mean for cultivar } \\
(\mathrm{Cv})\end{array}$ & 283.96 & 241.44 & 262.70 & 1402.9 & 1161.9 & 1282.4 & 142.14 & 145.26 & 143.70 & 186.94 & 160.23 & 173.59 \\
\hline \multirow{3}{*}{\multicolumn{2}{|c|}{$\begin{array}{c}\mathrm{NIR}_{\alpha=0.05} \text { dla: } \mathrm{Cv} \\
\mathrm{Ct} \\
\mathrm{Cv} \times \mathrm{Ct}\end{array}$}} & & 25.85 & & & 175.1 & & & n.s. & & & 14.47 \\
\hline & & & n.s. & & & 87.9 & & & n.s. & & & n.s. \\
\hline & & & n.s. & & & 204.8 & & & n.s. & & & n.s. \\
\hline
\end{tabular}

n.s.-no significant. 
It was shown that only the content of magnesium and calcium in maize grain depended on the date of sowing of this plant. Plants sown earlier contained more of the above-mentioned components: $10.1 \%$ and $18 \%$ more, respectively. Covering maize plants with polyethylene foil at the beginning of the vegetation period favoured the accumulation of dry matter in the grain. A similar tendency, however, was not statistically confirmed, but was also observed in the case of carotenoids. Grain of plants which were cultivated without protection accumulated significantly more vitamin $C$ (on average $12 \%$ more) and potassium (on average $11.4 \%$ more) in comparison with plants covered with foil. The same significance group included the results concerning plants covered with polypropylene non-woven fabric.

\section{Discussion}

Low soil and air temperatures hinder the germination of sweet maize seeds and their early growth. In the experiment, the soil temperature at the depth of $5 \mathrm{~cm}$ was within the range of the minimum germination temperature for maize, i.e., above $10^{\circ} \mathrm{C}$, according to Reference [10], or it was significantly higher, especially in the second sowing period. Ben-Asher et al. reported that the optimum sowing date for maize seeds is when the soil temperature is above $15{ }^{\circ} \mathrm{C}$. Similarly, Rattin et al. [12] concluded that, for the proper growth of maize roots and nutrient uptake, it is necessary to limit the adverse effects of low temperature by using covers. Hasell et al. [5] found a difference in thermal requirements between varieties belonging to different variety groups. Those in the super sweet group (sh2) had higher thermal requirements than those belonging to the se and su groups.

$\mathrm{Bu}$ et al. [25] found that foil covers have a positive effect on plant emergence, modifying microclimate conditions and contributing to soil temperature increase. The use of plastic sheeting in maize cultivation is widely used in cold spring regions, where the modified microclimate has a positive effect on maize yield and water storage $[2,26,27]$. The experiment showed that the use of polyethylene film or polypropylene non-woven fabric contributes to an increase in soil temperature during plant germination and emergence, as well as during the initial phase of plant growth, by an average of $2.3^{\circ} \mathrm{C}$ and $0.7^{\circ} \mathrm{C}$. Aguyoh et al. [28] indicated that, under transparent film, the minimum soil temperature was $2.1-2.2{ }^{\circ} \mathrm{C}$ higher than that of uncovered soil. An improvement of thermal conditions was also confirmed by the difference between the total effective temperatures calculated for the sites where the protective systems were applied and control plots. In the first sowing period, this was $36.2 \%$ on average, while it was $31.7 \%$ in the second period. In many studies it has been confirmed that favourable thermal and humidity conditions under covers have a positive effect on germination and faster initial growth in the critical period and undoubtedly result in higher plant productivity $[7,29,30]$. Kwabiah $[2,31]$ found that soil temperature has a greater effect on maize emergence than air temperature. Low soil temperature slows down germination, delays emergence and inhibits the initial growth of maize. Similarly, in our studies, a higher average temperature and the sum of effective temperatures under cover from foil or non-woven fabric improved grain germination and accelerated vegetative development of maize plants, as evidenced by the higher height of these plants. The studies conducted by Gordon et al. [16] also showed the effect of flat non-woven fabric on the development of pumpkin plants. Plants were 30\% higher but formed shoots of smaller diameter than in cultivation without covers.

Biometric measurements revealed that the type of covers used had an impact on the quality parameters of maize cobs. Kwabiah [2] showed an average increase in the index calculated on the basis of 5 morphological characteristics of maize, from 0.3 points (when maize was sown at the end of May) to 0.8 points (when maize was sown on 1 May). Covering the plants with PE foil at the beginning of the growth increased, on average, the weight of cobs and their diameter by $11.2 \%$ and $7.2 \%$, respectively. The best effect was achieved by using transparent and red PE film. The longest cobs were obtained in control plots and in sites where PP non-woven fabric was used. A higher increase in the weight of husker cobs under the influence of the covering (by 9-25\%) was obtained in a Canadian study by the authors of Reference [2]. The growth rate depended on the date of sowing and the hybrid used. 
Kara and Atar [7] also observed a positive effect of covering of the cultivation area with transparent $\mathrm{PE}$ foil in the form of increasing not only the weight and diameter, but also the length of maize cobs. In the presented study, the size of the cobs also depended on the maize variety. At the same time, no influence of the maize sowing date on the quality parameters was demonstrated, in contrast to the studies in Reference [7], which proved that, in the climatic conditions of Turkey, shifting the sowing date from 1 April to 15 April or 1 May significantly improved the quality parameters of maize cobs. In studies carried out in Newfoundland, delaying the sowing of maize by 14 and 28 days had a positive effect on the yield of cobs, which increased by $10 \%$ and $29 \%$, respectively [2]. At the same time, this author showed a significant impact on the yield of interaction between sowing date and foil covering. Covering plants sown with foil on 1 and 15 May brought a significant increase in the total and commercial yield of cobs, $12 \%$ and $17 \%$, and $5 \%$ and $6 \%$, respectively. At the third sowing date (29 May), the increase in yield obtained after covering with foil was not statistically significant. Kara and Atar [7] observed a small, but statistically significant increase in the yield of cobs after covering maize for two weeks. In our own research, the beneficial effect of covering maize with covers was found especially at the second sowing date and the yield of maize grown under covers in comparison with the control plots reached $36.5 \%$ while for the first sowing date, the difference was $25.7 \%$.

Our own research demonstrated a small influence of the analysed factors on the biological value of the yield. The greatest differences in the content of nutrients in the grains were observed between the varieties, while the smallest differences were noted between sowing dates. The tendency to increase the amount of dry matter and decrease the amount of vitamin $C$, potassium and phosphorus after application of colourless, red or green polyethylene film at the beginning of maize growth period was proven. The determined content (within the average of $19.47-25.32 \%$ dry matter, $9.45-11.42 \mathrm{mg} 100 \mathrm{~g}^{-1}$ vitamin C and $6.83-8.90 \%$ of total sugars) corresponds to what the author of Reference [32] showed in his research.

\section{Conclusions}

The field experiment carried out into the optimisation of sweet maize production showed a similar effect of polypropylene foil (regardless of colour) on the thermal conditions under the covers. During the research years, the accumulated daily sum of temperatures was 70 to 150 degrees Celsius higher than the sum of temperatures on maize not covered. Directly after the removal of covers, maize plants were as much as $53 \%$ higher than in the control plots. The above relationship was maintained during the next month of vegetation and in the second measurement this difference was $19 \%$. The use of covers had an impact on the morphological characteristics of maize cobs and their yield. Covering with PE compared to the control resulted in a $1 / 3$ increase in the cob yield. A greater difference between the PE and the control crop was noted at the first sowing date (range to $41 \%$ ).

When growing sweet maize for early harvest, use of perforated foil is recommended, but if cultivation is to proceed without a cover, sowing delay is recommended. Signet F1 is recommended for late sowing. Average yield was 50.6\% higher when maize sowing was delayed, while for Rustler F1, this difference was only $7 \%$. The use of this method and the delay in maize vegetation by two weeks resulted in a $42 \%$ increase in the yield and number of commercial cobs.

Our own results showed a 1 percentage point (p.p.) higher accumulation of total sugars in maize cobs from Signet F1 hybrid. A particularly large impact was demonstrated after the use of PE, PER and PEG. Similar to the total sugar content, a high potassium content was recorded when the analyses were carried out in the same variety.

Future research work is necessary for better development of sweet maize cultivation for very early harvesting.

Author Contributions: Conceptualization, K.A.-S. and J.S.; methodology, K.A.-S. and J.S.; software, K.A.-S. and J.S.; validation J.S.; formal analysis, K.A.-S.; investigation, K.A.-S. and J.S.; resources, K.A.-S.; data curation, K.A.-S. and J.S.; writing — original draft preparation, K.A.-S. and J.S.; writing—review and editing, K.A.-S.; visualization, 
K.A.-S. and J.S.; supervision, J.S.; project administration, K.A.-S. and J.S.; funding acquisition, K.A.-S. and J.S. All authors have read and agreed to the published version of the manuscript.

Funding: This research was supported by the Wroclaw University of Environmental and Life Sciences Fund.

Conflicts of Interest: The authors declare no conflicts of interest.

\section{References}

1. Anioł, M.; Sowiński, J.; Adamczyk, J.; Baraszkiewicz, M.; Potaniec, B.; Zieliński, P. Analysis of zeaxanthin and lutein content in forms of corn grain and selected varieties available on the Polish market. Przemyst Chem. 2012, 91, 666-670.

2. Kwabiah, A.B. Growth and yield of sweet corn (Zea mays L.) cultivars in response to planting date and plastic mulch in a short-season environment. Sci. Hortic. 2014, 102, 147-166. [CrossRef]

3. Ahmad, I.; Khaliq, T.; Ahmad, A.; Basra, S.M.A.; Hasnain, Z.; Ali, A. Effect of seed priming with ascorbic acid, salicylic acid and hydrogen peroxide on emergence, vigor and antioxidant activities of maize. Afr. J. Biotechnol. 2012, 11, 1127-1132.

4. Stone, P.J.; Sorensen, I.B.; Jamieson, P.O. Effect of soil temperature on phenology, canopy development, biomass and yield of maize in a cool-temperate climate. Field Crop. Res. 1999, 63, 169-178. [CrossRef]

5. Ben-Asher, J.; Garcia, A.G.Y.; Hoogenboom, G. Effect of high temperature on photosynthesis and transpiration of sweet corn (Zea mays L. var. rugosa). Photosynthetica 2008, 46, 595-603. [CrossRef]

6. Hassell, R.L.; Dufault, R.J.; Phillips, T.L. Low temperature germination response of su, se, and sh2 sweet corn cultivars. Hort. Technol. 2003, 13, 136-141. [CrossRef]

7. Kara, B.; Atar, B. Effects of mulch practices on fresh ear yield and yield components of sweet corn. Turk. J. Agric. For. 2013, 37, 281-287.

8. Sbrussi, C.A.G.; Zucareli, C. Germination of corn seeds with different levels of vigor in response to differents temperatures. Ciências Agrárias Londrina 2014, 35, 215-226. [CrossRef]

9. Commuri, P.D.; Jones, R.J. High temperatures during endosperm cell division in maize. A genotypic comparison under in vitro and field conditions. Crop. Sci. 2001, 41, 1122-11301. [CrossRef]

10. Abd El-Hamed, K.E.; Elwan, M.W.M.; Shaban, W.I. Enhanced sweet corn propagation: Studies on transplanting feasibility and seed priming. Veg. Crop. Res. Bull. 2011, 75, 31-50. [CrossRef]

11. Öktem, A.; Öktem, A.G.; Coşkun, Y. Determination of sowing dates of sweet corn (Zea mays L. saccharata Sturt.) under Şanlıurfa conditions. Turk. J. Agric. For. 2004, 28, 83-91.

12. Rattin, J.; Molinari, J.; Giardina, E.; Di Benedetto, A. Tools for improving sweet corn yield. Int. J. Adv. Agric. 2018, 3, 1-14.

13. Nagy, J. Effect of sowing date on the yield and quality of maize hybrids with different growing seasons. Acta Agron. Hung. 2009, 57, 389-399. [CrossRef]

14. Wilcox, G.E.; Pfeiffer, C.L. Temperature effect on seed germination, seedling root development and growth for several vegetables. J. Plant Nutr. 1990, 13, 1393-1403. [CrossRef]

15. Rattin, J.; Wagner, P.; Ferreyro, D.; Riverti, A.; Giardina, E.; Di Benedetto, A. Roots partially drive super sweet maize yield. Am. J. Exp. Agric. 2017, 16, 1-17.

16. Zhang, X.D.; Yang, L.C.; Xue, X.K.; Kamran, M.; Ahmad, I.; Dong, Z.Y.; Liu, T.N.; Jia, Z.K.; Zhang, P.; Han, Q.F. Plastic film mulching stimulates soil wet-dry alternation and stomatal behavior to improve maize yield and resource use efficiency in a semi-arid region. Field Crop. Res. 2019, 233, 101-113. [CrossRef]

17. Kołota, E.; Adamczewska-Sowińska, K.; Uklańska-Pusz, C. Yielding and nutritional value of Japanese bunching onion in relation to the date of planting and type of flat cover. Folia Hortic. 2013, 25, 93-100. [CrossRef]

18. Moreno, D.A.; Víllora, G.; Soriano, M.T.; Castilla, N.; Romero, L. Sulfur, chromium, and selenium accumulated in Chinese cabbage under direct covers. J. Environ. Manag. 2005, 74, 89-96. [CrossRef]

19. Siwek, P.; Lipowiecka, M. Cucumber cultivation under plastic covers-Economic results. Folia Hortic. 2004, 16, 49-55.

20. Biesiada, A. Effect of flat covers and plant density on yielding and quality of kohlrabi. J. Elementol. 2008, 13, 167-173.

21. Kołota, E.; Adamczewska-Sowińska, K. Application of synthetic mulches and flat covers with perforated foil and agrotextile in zucchini. Acta Sci. Pol. Hortorum Cultus 2011, 10, 179-189. 
22. Wierzbicka, B.; Majkowska-Gadomska, J.; Nowak, M. Concentrations of some bionutrients in parthenocarpic cucumber fruits in forced cultivation. Acta Sci. Pol. Hortorum Cultus 2007, 6, 3-8.

23. Zawiska, I.; Siwek, P. The effect of biodegradable direct covers on the root development, yield and quality of cucumber. Folia Hortic. 2014, 26, 43-48. [CrossRef]

24. Electronic Statistics Textbook, version 13.1; StatSoft, Inc.: Tulsa, OK, USA, 2016.

25. Bu, L.; Liu, J.; Zhu, L.; Luo, S.; Chen, X.; Li, S.Q.; Hill, R.L.; Zhao, Y. The effects of mulching on maize growth, yield and water use in a semi-arid region. Agric. Water Manag. 2013, 123, 71-78. [CrossRef]

26. Li, S.; Kang, S.; Zhang, L.; Ortega-Farias, S.; Li, F.; Du, T.; Tong, L.; Wang, S.; Ingman, M.; Guo, W. Measuring and modeling maize evapotranspiration under plastic film-mulching condition. J. Hydrol. 2013, 503, 153-168. [CrossRef]

27. Xu, J.; Li, C.; Liu, H.; Zhou, P.; Tao, Z.; Wang, P.; Meng, Q.; Zhao, M. The Effects of Plastic Film Mulching on Maize Growth and Water Use in Dry and Rainy Years in Northeast China. PLoS ONE 2015, 10, e0125781. [CrossRef]

28. Aguyoh, J.; Taber, H.G.; Lawson, V. Maturity of Freshmarket sweet corn with directseeded plants, transplants, clear plastic mulch, and rowcover combinations. Hort. Technol. 1999, 9, 420-425. [CrossRef]

29. Ndubuisi, N.C. Physical properties of an ultisol under plastic film and no-mulches and their effect on the yield of maize. J. Am. Sci. 2009, 5, 25-30.

30. Kasirajan, S.; Ngouajio, M. Polyethylene and biodegradable mulches for agricultural applications: A review. Agron. Sustain. Dev. 2012, 32, 501-529. [CrossRef]

31. Kwabiah, A.B. Performance of silage corn (Zea mays L.) in a cool climate ecosystem: Effects of photodegradable plastic mulch. Can. J. Plant Sci. 2003, 83, 305-312. [CrossRef]

32. Rosa, R. Quality of sweet corn yield depending on winter catch crops and weed control method. Acta Sci. Pol. Hortorum Cultus 2015, 14, 59-74.

(C) 2020 by the authors. Licensee MDPI, Basel, Switzerland. This article is an open access article distributed under the terms and conditions of the Creative Commons Attribution (CC BY) license (http://creativecommons.org/licenses/by/4.0/). 